\title{
МОДЕЛИ ВЗРОСЛЕНИЯ \\ РАЗНЫХ ПОКОЛЕНИЙ РОССИЯН
}

\author{
ЕКАТЕРИНА МИТРОФАНОВА
}

\begin{abstract}
На базе данных обследования «Родители и дети, мужчины и женщины в семье и обществе» (2011 г., 5451 человек) проведен количественный анализ наступления стартовых событий жизни, маркируюших взросление. В качестве таких событий взяты получение профессионального образования, первое трудоустройство, первое отделение от родителей, первое партнерство (незарегистрированные отношения с совместным проживанием), первый брак и рождение первого ребенка.
\end{abstract}

Результаты визуализировань на демографической сетке Лексиса, что наглядно представляет влияние исторического и институционального контекста на организацию жизненного пути индивидов. Действуюшие законодательные и сочиальные нормы задают граниџы вариативности сценариев взросления в каждый момент времени и определяют скорость обновления социальных практик.

Выявлены три модели перехода во взрослую жизнь в России: «советская» (характерна для поколений 1940-49, 1950-59, 1960-69 годов рождения), «переходная» (поколения 1930-39 и 1970-79 годов рождения) и «постсоветская» (поколение 1980-86 годов рождения). Сравнение моделей перехода во взрослую жизнь в России и европейских странах показало наличие конвергенции паттернов взросления между странами, а также выявило запаздывание демографического перехода в России примерно на 20-25 лет, что подтверждает предположение о стадиальности модернизаџионного проиесса.

Ключевые слова: Россия, взросление, переход во взрослую жизнь, поколения, стартовые события жизни, демографические события, сочиоэкономические события, демографический переход, брачность, рождаемость, партнерство, трудоустройство, образование, отделение от родителей.

\section{ВВЕДЕНИЕ}

В течение многих тысячелетий человеческие общества находились под постоянными рисками угроз выживанию, поэтому главным фокусом деятельности взрослых членов общества было обеспечение средств к существованию и воспроизводство населения. Так как средняя продолжительность жизни составляла всего 20-30 лет, было необходимо максимально эффективно использовать располагаемый бюджет времени и начинать участвовать в трудовой деятельности и воспроизводстве потомства как можно раньше.

ЕКАТЕРИНА СЕРГЕЕВНА МИТРОФАНОВА (mitrofanovy@yandex.ru), НАЦИОНАЛЬНЫЙ ИССЛЕДОВАТЕЛЬСКИЙ УНИВЕРСИТЕТ «ВЫСШАЯ ШКОЛА ЭКОНОМИКИ», РОССИЙСКАЯ АКАДЕМИЯ НАРОДНОГО ХОЗЯЙСТВА И ГОСУДАРСТВЕННОЙ СЛУЖБЫ ПРИ ПРЕЗИДЕНТЕ РОССИЙСКОЙ ФЕДЕРАЦИИ, РОССИЯ.

СТАТЬЯ НАПИСАНА ПО ИТОГАМ ПРОЕКТА ПРОГРАММЫ ФУНДАМЕНТАЛЬНЫХ ИССЛЕДОВАНИЙ НАЦИОНАЛЬНОГО ИССЛЕДОВАТЕЛЬСКОГО УНИВЕРСИТЕТА ВЫСШЕЙ ШКОЛЫ ЭКОНОМИКИ НИУ ВШЭ 2019 ГОДА.

СТАТЬЯ ПОСТУПИЛА В РЕДАКЦИЮ В НОЯБРЕ 2019 Г. 
Стандартные расписания жизни не предусматривали длительного периода подготовки ко взрослости. В большинстве традиционных обществ существовали короткие, четко регламентированные обряды инициации. Эти ритуалы обретения статуса взрослого были формальными, обязательными и достижимыми практически всеми членами общества. Они играли важную роль, так как публично и явно обозначали момент, с которого индивиды переходили из группы детей или подростков в группу взрослых. Также эти ритуалы снижали напряжение и неопределенность, возникающие из-за изменения как социального статуса, так и организации жизни индивида при его переходе в новую возрастную группу (Ремшмидт 1994). Обряды инициации обеспечивали преемственность поколений и неизменность общественного устройства, в результате которого «прошлое родителей становилось будущим детей» (Мид 1988).

За последние полтора-два века жизнь общества и индивида претерпела серьезные трансформации как количественного, так и качественного свойства. Население развитых стран стало жить не только в два-три раза дольше, но и значительно более здоровой, наполненной удобствами и технологиями жизнью. В постиндустриальном обществе базовые потребности у большинства людей удовлетворены, поэтому задача выживания и связанная с ней необходимость раннего и всеобщего деторождения уже не стоит так остро, как прежде. В результате фокус жителей развитых стран с задачи выживания сместился на улучшение качества жизни, индивидуальное развитие и инвестиции в человеческий капитал.

Исследования современных западных обществ показывают, что удвоение продолжительности жизни приводит к «инфляции» возраста (Shoven, Goda 2011) и сдвигает возрастные границы разных этапов жизни. Ускоренное взросление перестает быть необходимым, а из-за многократного усложнения социально-экономического и политического устройства общества, появления профессий, требующих долгой подготовки, актуальной становится тенденция замедления и удлинения перехода во взрослую жизнь.

Процесс подготовки индивида ко взрослой жизни становится таким сложным и многоаспектным, что в систему простых ритуалов и жестких схем он больше не вписывается. Из обобщения опыта развитых стран (Billari, Liefbroer 2010; Arnett 2012) известно, что происходит размывание возрастных границ и критериев взросления; замена внешней регламентации процесса перехода ко взрослой жизни на внутреннюю - более вариативную, индивидуальную и рефлективную. То есть меняются и количественные, и качественные аспекты взросления.

В то же время мы пока еще мало знаем о том, как изменяется взросление в России, так как крупных комплексных исследований, посвященных изучению этого вопроса, немного. Демографы и социологи фиксируют, что после распада СССР наступление отдельных демографических и социоэкономических событий в жизни людей стало меняться (Архангельский 2013; Блюм, Лефевр и др. 2010; Гимпельсон, Зудина 2017; Захаров 2009; Здравомыслова, Шурыгина 2001; Константиновский 2008; Магун, Энговатов 2006; Mills 2004; Potârcă, Mills, Lesnard 2013).

Наступление стартовых событий в совокупности (холистический подход), а не по отдельности (событийный подход), на российских данных изучается довольно редко и чаще 
всего с ограничениями по количеству рассматриваемых событий и разрезов анализа. Например, в работе 2010 г. (Блюм, Себий, Захаров 2010) сравнивается взросление поколений россиян и французов, но не уделяется внимание гендерной и другим важным видам дифференциации. В другом исследовании (Захаров 2009) изучено только взросление женщин, а взросление мужчин не рассмотрено. Еще в одной публикации рассмотрены оба пола и учтен кейс России, однако он подробно не разобран (Zsolt, Murinkó, Settersten 2014).

В данном исследовании мы учитываем мировой опыт изучения взросления, а также эмпирические свидетельства трансформации демографического и социоэкономического поведения в России. Эмпирический анализ, представленный в работе, позволяет получить комплексное представление о процессе перехода во взрослую жизнь в России и сопоставить наблюдаемые тенденции с примерами европейских стран.

\section{ТЕОРЕТИЧЕСКИЕ РАМКИ}

Взросление как процесс, как специфический этап жизни - относительно новый для человечества феномен, который изучается наукой всего около ста лет. Интерес к этому этапу жизни проявляют, опираясь на свои подходы, самые разные дисциплины: философия, психология, социология, демография, антропология и другие науки, - но пока единой концепции взросления и комплексной методологии анализа этого процесса не предложено.

Можно дать следующее обобщающее определение взросления: это комплексный процесс трансформации ребенка и обретения им опыта и статусов, позволяющих занять самостоятельную позицию в обществе. Взросление - многосоставной и многоуровневый процесс. Он включает в себя хронологическую, биологическую, правовую, психоэмоциональную, социальную и демографическую компоненты и протекает на макро-, мезо- и микроуровнях.

Взросление на макроуровне - это процесс, благодаря которому в процессе смены поколений происходит обновление социальных практик и нормативных моделей поведения и нормативных сценариев, содержащих социально и гендерно дифференцированные последовательности событий жизненного пути.

Взросление на мезоуровне - это процесс физической, экономической и психологической сепарации детей от родителей, т. е. процесс отделения, обретения детьми самостоятельности.

Взросление на микроуровне - это процесс, при помощи которого индивид встраивается в существующую социальную структуру посредством интериоризации существующих в обществе норм относительно того, какие характеристики должны быть присущи взрослому человеку.

В научной среде еще не сложилось консенсуса относительно того, как и какие компоненты взросления необходимо изучать, чтобы получить наиболее полное и объективное представление об этом процессе. Психологи, в основном, используют качественные методы анализа и изучают отношение индивидов к процессу становления взрослым, а также набор личностных компетенций, маркирующих взросление (Arnett 2012). 
Демографы и социологи чаще всего изучают фактологический слой взросления - т.е. объективные, наблюдаемые события, маркирующих взросление. К таким событиям обычно относят следующие: завершение получения образования, первое трудоустройство, первое покидание родительского дома, первое партнерство (совместное проживание без регистрации отношений), первый брак, рождение первого ребенка (Billari et al. 2005; Billari, Liefbroer 2010; Buchmann 1989; Liefbroer 1999).

Концептуальные рамки междисциплинарного изучения организации жизни индивидов очерчивает концепџия жизненного пути (КЖП). Ее положения гласят, что современные жизненные пути перестали быть «стандартными», институционализированными, одинаковыми для всех и становятся индивидуализированными или «настраиваемыми» (choice biography) (Giddens 1994; Heinz, Marshall 2003; Huinink 2013). Изучению перехода во взрослую жизнь (transition to adulthood) в КЖП уделяется отдельное внимание, так как на этом этапе жизни происходит наиболее высокая концентрация значимых событий, меняющих социальный статус человека и устройство его жизни (Billari, Liefbroer 2007; Rindfuss 1991).

Еще один теоретический подход, систематизирующий знания о наступлении биографических событий, в том числе стартовых, - это теория демографического перехода (ТДП). В ее рамках, в основном, изучается наступление демографических событий, но объединение КЖП и ТДП позволяет получить более объемное представление о взрослении. Перемены во взрослении тесно сопряжены с демографическим переходом и представляют собой важную часть демографической модернизации общества.

Теория демографического перехода предполагает, что существует несколько стадий демографической модернизации. На первом этапе изменяются количественные показатели основных демографических процессов: баланс высокой смертности и высокой рождаемости сменяется балансом низкой смертности и низкой рождаемости (Lesthaeghe 1995). На втором этапе демографического перехода происходят изменения в организации семейной жизни и разделение сексуального, репродуктивного и матримониального поведения (Вишневский 1976: 158). Этот второй этап часто называют «вторым демографическим переходом» (van de Kaa 1987).

Демографический переход в разных странах начинается в разное время и идет с разной скоростью. Среди европейских стран признаки демографической модернизации сначала появились в странах Западной Европы, а затем - Восточной Европы (Frejka, Zakharov 2012; Puur et al. 2012a; Puur et al. 2012b), то же произошло и со вторым демографическим переходом. Основные признаки второго демографического перехода: откладывание браков и деторождений; рост популярности партнерств и снижение популярности браков; снижение числа рожденных детей и повышение числа детей, рожденных вне зарегистрированного брака (Lesthaeghe, Neels 2002; Вишневский 2006; Zakharov 2008).

Объединяя представления КЖП и ТДП, социологи и демографы сформировали три основные гипотезы, интерпретирующие изменения, происходящие с переходом во взрослую жизнь: одни исследователи полагают, что между странами происходит конвергенция, т. е. сближение паттернов взросления, другие - что происходит дивергенция, 
т. е. нарастание региональных различий, а третьи - что общее движение модернизационного процесса происходит в разных странах похожим образом, но некоторые страны отклоняются от нормативного образца в силу специфических социокультурных особенностей.

Подтверждением предположения о дивергенции моделей взросления и отдельных поведений, маркирующих переход во взрослую жизнь, служат исследование Хайнала, описывающее и объясняющее исторические различия в западно- и восточноевропейской брачности (Hajnal 1965), а также более современные работы: классификация моделей взросления в европейских странах (Cavalli, Galland 1993); кластеризация европейских стран в зависимости от типов семейной политики (Ejrnœs, Boje 2008); классификация режимов социальной политики в европейских странах (Esping-Andersen 1990; 2007); взаимосвязь особенностей перехода во взрослую жизнь с ограничениями и возможностями, формируемыми режимами социальной политики, функционированием рынка труда и семейным укладом (Vogel 2002). Основной вывод этих исследований заключается в следующем: наиболее быструю трансформацию моделей взросления демонстрируют западные и северные страны Европы с более либеральными социальными нормами в отношении организации семейной жизни и более гендерно сбалансированной семейной и социальной политикой государства, тогда как восточные и южные страны Европы с более фамилистской и гендерно-ассиметричной государственной политикой демонстрируют сохранение прежних, более традиционных норм и моделей поведения.

Объяснительные концепции, предполагающие конвергенцию моделей взросления, не отвергают культурно-национальных и региональных различий, но утверждают, что со временем эти различия ослабевают и происходит общее движение в направлении модернизации демографического и социоэкономического поведения. В поддержку идеи о конвергенции выступает исследование Ф. Биллари и А. Лифброера (Billari, Liefbroer 2010), которые изучили изменение следующих характеристик наступления стартовых событий в европейских странах: времени (timing), интенсивности или скорости (tempo) и последовательности (sequence). «Традиционную» модель взросления они описали как «раннюю, ускоренную и простую» (события наступали рано, с маленькими интервалами и в едином почти для всех порядке), а современную - как «позднюю, растянутую $u$ сложную». Результаты этого исследования согласуются с предположениями теории второго демографического перехода и показывают, что возраст наступления стартовых событий, особенно демографических, в современных обществах повышается. За счет того, что возраст наступления социоэкономических событий меняется меньше, переход во взрослую жизнь начинается примерно в том же возрасте, что и раньше, а заканчивается позже - т. е. переход во взрослую жизнь растягивается во времени. Последовательность наступления событий становится все более мозаичной, индивидуализированной и менее предсказуемой.

Идею о конвергенции моделей взросления поддерживают сравнительные исследования формирования семьи во Франции, Румынии и России (Potârcă et al. 2013), в Канаде, Нидерландах и России (Mills 2004), взросления в Белоруссии (Лапето, Терещенко, Шавердо 2018) и обзор работ по взрослению европейцев (Buchmann, Kriesi 2011). 
Третья точка зрения, занимающая срединную позицию между гипотезами о дивергенции и о конвергенции, предполагает, что общее направление изменений паттернов взросления у большинства стран совпадает, но у некоторых стран сохраняется ряд специфических региональных особенностей.

Изучение взросления девушек в разных странах Европы (Захаров 2009) показало наличие различий не только в тайминге и последовательности наступления стартовых событий, но и в том, какие события жители разных стран считают индикаторами взрослости (дивергенция). В восточноевропейских странах, а также в Португалии, Франции и на Кипре с обретением женщиной статуса взрослой в большей мере связано создание семьи и материнство (которое достаточно часто сочетается с полной занятостью). В западно- и североевропейских странах, по мнению респондентов, для взросления важно трудоустройство и покидание родительского дома. С.В. Захаров соглашается с тем, что в целом происходит конвергенщия моделей взросления как результат «общего для развитых стран переходного процесса к некоему “новому” расписанию человеческой жизни» (Захаров 2009). Но он также подтверждает сохранение региональной дифференцииации моделей взросления, обусловленной историко-культурными особенностями разных стран.

A. Пуур и соавторы в своем исследовании (Puur et al. 2012a; Puur et al. 2012b) нашли подтверждение как стадиальности изменений в брачно-партнерском поведении (конвергенция), так и наличия региональной дифференциации (дивергенция): в странах восточной Европы переход к новой модели брака начался на несколько десятилетий позже, чем в западной Европе, причем сначала (через 15-20 лет) переход осуществили Восточная Германия и Эстония, а затем (через 20-25 лет) - Болгария, Венгрия, Литва, Россия и Румыния. Авторы выявили, что процесс модернизации демографического поведения действительно проходит определенные стадии, но культурно-исторические нормы, действующие в разных странах, могут оказывать существенное влияние на содержание и скорость протекания модернизационного процесса.

Обобщим выводы всех перечисленных подходов: на сегодняшний день в ряде стран сохраняются региональные особенности в переходе во взрослую жизнь, но признаки демографического перехода и сближение моделей взросления прослеживается во всех европейских странах, в том числе и в России (Архангельский 2013; Долбик-Воробей 2003; Захаров 2007; Чернова 2012; Шабунова, Калачикова 2015).

В данной работе мы решаем следующие задачи: диахроническую (сравниваем различные поколения россиян между собой) и синхронную (сравниваем последние российские поколения с их европейскими сверстниками и демонстрируемыми ими трендами). Мы изучаем, изменяются ли модели взросления современной молодежи в соответствии с треками, задаваемыми западноевропейскими странами (идея конвергенции) или сохраняются модели взросления, унаследованные от советских поколений (идея дивергенции, сохранения региональных различий). Пользуясь представленными объяснительными концепциями, мы предполагаем, что в целом переход во взрослую жизнь молодых поколений модернизируется, но, в зависимости от индивидуальных характеристик респондентов (пола, принадлежности к поколению, уровня образования 
и т.д.), разница между советскими и современными поколениями будет ослабевать или усиливаться.

\section{ДАННЫЕ И МЕТОДЫ АНАЛИЗА}

В нашем исследовании мы изучаем биографии россиян и операционализируем взросление через наличие событий, маркирующих переход во взрослую жизнь. Мы делим эти стартовые социодемографические события на две группы: соииоэкономические (завершение получения образования, первое трудоустройство, первое покидание родительского дома) и демографические (первое партнерство, первый брак, рождение первого ребенка).

В качестве базы данных взяты результаты российской части международной программы сравнительных выборочных исследований Европейской экономической комиссии ООН «Поколения и гендер» (Generations and Gender) - репрезентативного для России обследования «Родители и дети, мужчины и женщины в семье и обществе» (РиДМиЖ). Обследование было проведено в 2004, 2007 и 2011 гг. по унифицированному для всех стран вопроснику. Для целей данного исследования была сформирована панельная выборка, то есть отобраны респонденты, участвовавшие во всех трех волнах обследования (5451 респондент). Все биографии взяты по состоянию на 2011 г. В выборку вошли представители поколений, родившихся между 1930 и 1986 гг. В качестве поколенческого шага взят 10-летний интервал. Последняя группа поколений - усеченная из-за панельной природы данных: в 2004 г. самыми молодыми респондентами были те, кто родился в 1986 г.

Наступление стартовых событий изучалось с использованием таких методов описательной статистики, как частотный анализ, таблицы сопряженности, расчет медианных возрастов наступления событий. Для оценки значимости выявленных различий использованы критерий хи-квадрат для фактов наступления событий и критерий КраскалаУоллиса для независимых выборок - для проверки различий в медианных возрастах.

Мы использовали два взаимодополняющих подхода к изучению взросления: событийный подход (анализ наступления стартовых событий по отдельности) и холистический подход (анализ взросления как единого процесса). Первый подход встречается в большинстве исследований демографов и социологов. Он дает полноценное представление об отдельных сферах жизни, например, брачной, образовательной и др. Однако, изучая взросление, мы имеем дело с целостным процессом, характеризующимся несколькими событиями (в нашем случае - шестью), которые могут встречаться на индивидуальных жизненных путях в самых разных комбинациях. Для того, чтобы определить, с какого события и в каком возрасте начинается взросление, необходимо выстроить все стартовые события по хронологии и определить, какое из них было первым и в каком возрасте оно произошло. То же самое - для второго, третьего и так далее, вплоть до последнего события. Таким образом, событийный и холистический подходы различаются методологически: в первом случае мы сравниваем события одинакового типа, а во втором - обезличиваем события, оставляя только их порядковые номера и возрасты, в которых они произошли. 
Холистический подход весьма информативен при анализе взросления, так как принимает в расчет порядок событий в индивидуальной биографии. Но этот подход очень чувствителен к набору событий, которые исследователи определяют в качестве маркирующих взросление. Так, наши предыдущие исследования показали, что партнерство не являлось распространенным и одобряемым стартовым событием в СCCP (Artamonova, Mitrofanova 2014; Артамонова, Митрофанова 2018), поэтому включать его в нормативный набор маркеров взрослости всех поколений было бы некорректно.

С учетом сказанного методологическая конструкция данного исследования выглядит следующим образом:

1. Анализ фактов и возрастов наступления каждого из шести стартовых событий (событийный анализ).

2. Анализ фактов и возрастов наступления событий в их хронологической последовательности, выделение первого и последнего в цепочке стартовых событий (холистический анализ). Партнерство исключено из нормативного набора событий как нетипичное для советского времени.

Для визуализации результатов анализа использована хорошо известная демографам сетка Лексиса. Ее особенность состоит в оперировании сразу тремя временными координатами: календарным годом (ось X), возрастом людей в каждый момент времени (ось Y) и годами их рождения, образующими поколения (диагональ). Эта диаграмма и используется нами для одновременного отображения всей совокупности демографических событий в жизни поколений.

\section{АНАЛИЗ ДАННЫХ}

Визуализации данных на диаграмме Лексиса предшествовал анализ фактов (Приложение 1) и медианных возрастов наступления каждого из стартовых событий по отдельности (Приложение 2). Затем были проанализированы медианные возрасты наступления первого и последнего события в цепочке стартовых событий (Приложение 3). Диаграмма Лексиса позволяет представить все результаты наглядно и соотнести их с историческим контекстом, сопутствующим взрослению (см. рисунок ниже).

Ось календарного времени (ось X) дает представление о том, в каком историческом контексте взрослело каждое поколение. В поле под осью X мы нанесли некоторые исторические события, которые могли оказать влияние на наступление стартовых событий. Более подробно эти события и их влияние мы опишем в следующих разделах статьи.

Ось возраста (ось Ү) начинается в точке достижения респондентами 15 лет и завершается в момент 30-летия, так как именно этим возрастом ограничиваются полученные медианные значения.

Диагональная ось содержит информацию о каждом рассматриваемом поколении. Цветные пиктограммы отображают результаты событийного анализа и располагаются соответственно медианным возрастам наступления стартовых событий (Приложение 2). Синим цветом обозначены пиктограммы мужчин, красным - женщин. 
Степень непрозрачности пиктограмм показывает, у какой доли представителей поколения есть конкретное событие. Интервалы между самым ранним и самым поздним стартовым событием объединены закрашенным цветовым «коридором». Таким образом, и пиктограммы, и закрашенные коридоры отражают информацию о наступлении стартовых событий по отдельности (событийный подход).

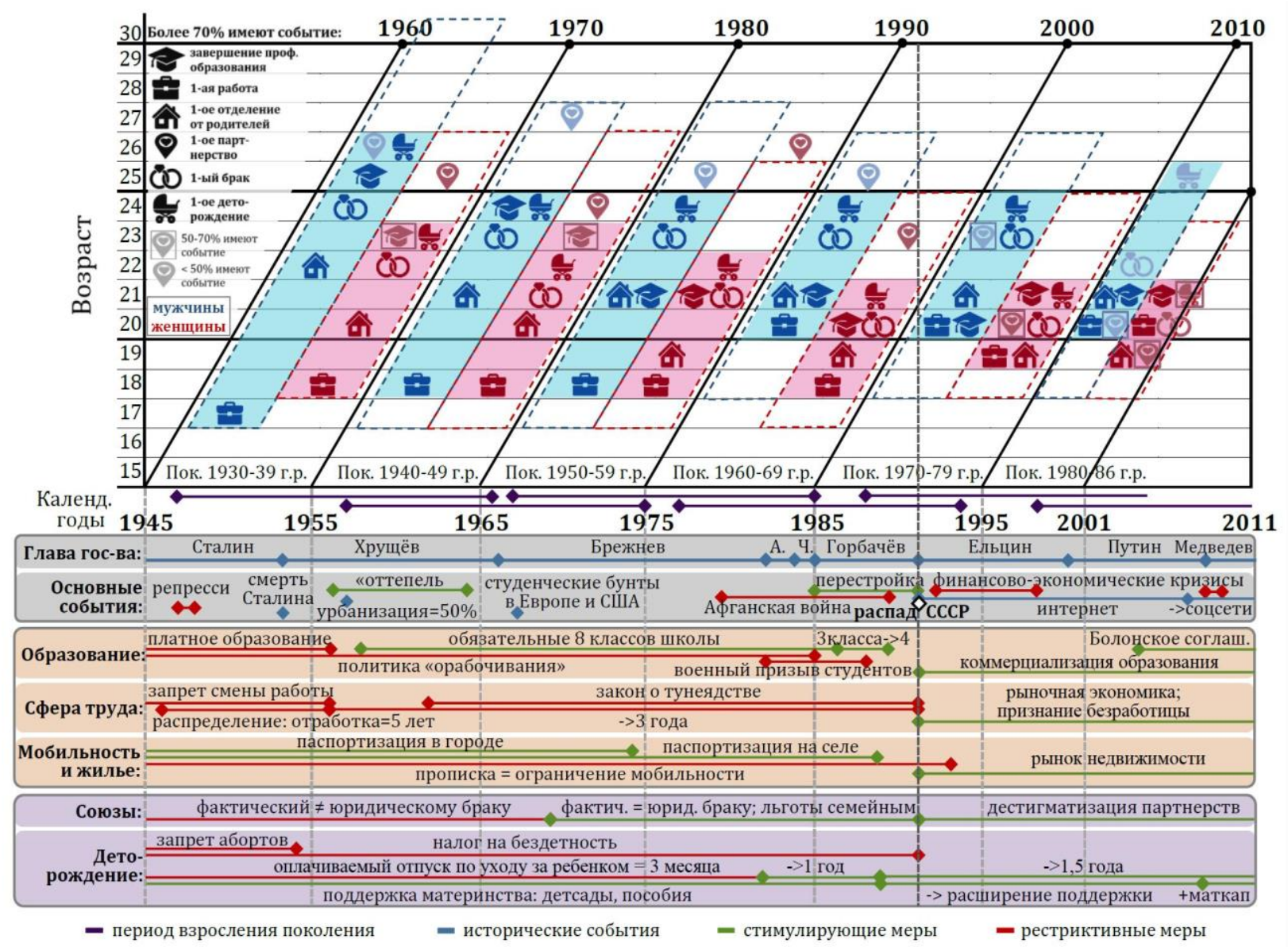

\section{Рисунок. Визуализация процесса взросления разными поколениями россиян в условиях существовавшего исторического контекста}

Источник: Составлено автором на основе панельных данных РиДМиЖ на 2011 г.

Примечания: А. - Андропов; Ч. - Черненко; -> сочсети - появление социальньх сетей; 3 класса->4 возможность пропустить 4-й класс иколь;; ->1 год - увеличение отпуска по уходу за ребенком до одного года; -> 1,5 года-увеличение отпуска по уходу за ребенком до 1,5 года; маткап-материнский капитал.

Примечания к сетке Лексиса: пиктограммы обозначают медианные возрасты наступления событий; закрашенные изветовые коридоры обозначают границы наступления событий по отдельности (событийный подход); пунктирные коридоры - интервал между первым и последним событием перехода во взрослую жизнь как единого прочесса (холистический подход); партнерства не включены в коридоры, так как не являлись обязательными для взросления в советское время.

Информация о наступлении всех стартовых событий как элементов единого процесса (холистический подход) содержится в пунктирных «коридорах», которые не совпадают с закрашенными. Нижнюю границу такого коридора задает первое событие (то, с которого начинается взросление), а верхнюю - то событие, которое наступило последним (Приложение 3). 
Ни закрашенные, ни пунктирные коридоры не включают партнерство, так как оно не входило в нормативный сценарий взросления в советское время.

В таблице, составленной на основе описанной схемы и данных о фактах и медианных возрастах наступления событий, обобщена информация о шести ключевых параметрах перехода во взрослую жизнь. Приведенные в таблице показатели не включают партнерство. На основе данных о длительности взросления и количестве наступивших событий рассчитана «скорость» взросления (Приложение 4), т.е. среднее число событий в год ${ }^{1}$.

Таблица. Классификация моделей взросления россиян

\begin{tabular}{|c|c|c|c|c|c|c|c|}
\hline Поколение & 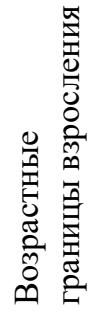 & 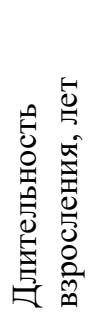 & 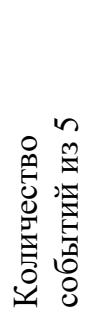 & 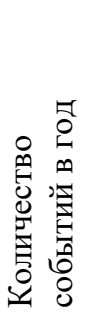 & $\begin{array}{c}\text { Последовательность } \\
\text { наступления событий** }\end{array}$ & 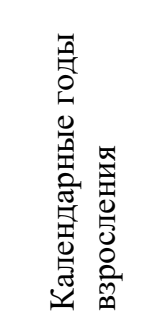 & 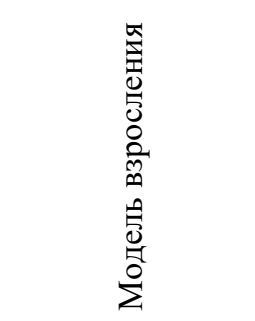 \\
\hline $1930-39$ & $17-27$ & 10 & 4,46 & 0,69 & \multirow{4}{*}{$\begin{array}{l}\text { 1. Трудоустройство } \\
\text { 2. Отделение от родителей } \\
\text { 3. Брак и деторождение } \\
\text { 4. Профессиональное образование } \\
\text { 5. Партнерство }\end{array}$} & $1947-1966$ & \multirow[t]{4}{*}{ «переходная» } \\
\hline $1940-49$ & $17-26$ & 9 & 4,57 & 0,80 & & $1957-1975$ & \\
\hline $1950-59$ & $17-26$ & 9 & 4,66 & 0,81 & & 1967-1985 & \\
\hline $1960-69$ & $17-25$ & 8 & 4,63 & 0,95 & & 1977-1994 & \\
\hline $1970-79 *$ & $18-25$ & 7 & 4,51 & 1,06 & 1. Трудоустройство & $1988-2004$ & «переходная» \\
\hline $1980-86^{*}$ & $18-23$ & 5 & 3,60 & 1,23 & $\begin{array}{l}\text { 2. Отделение от родителей } \\
\text { 3. Профессиональное образование } \\
\text { 4. Партнерство } \\
\text { 5. Деторождение } \\
\text { 6. Брак }\end{array}$ & 1998-2009 & «постсоветская» \\
\hline
\end{tabular}

Источник: Составлено автором на основе панельных данных РиДМиЖ на 20112.

Примечания: * - Для поколений, не окончивших переход во взрослую жизнь, представлены предварительные результаты; **-обозначения универсальности наступления событий:

универсальные события (есть у более чем 70\% респондентов); полууниверсальные события (есть у 50 70\% респондентов); неуниверсальные события (есть менее чем у 50\% респондентов).

Перечислим основные выводы по каждому из параметров взросления, представленных на схеме и в таблице.

Границы взросления меняются очень медленно. В среднем, для россиян характерно наступление стартовых событий в интервале от 17-18 и до 25-27 лет. Мужчины начинают переход во взрослую жизнь раньше женщин и в основном с социоэкономических событий. За счет того, что женщины интенсивнее обретают опыт в демографической сфере и быстро догоняют мужчин по уровню социоэкономических событий, взросление женщин происходит быстрее. К 25 годам у обоих полов в среднем уже имеется опыт двух из трех социоэкономических событий; демографических событий у женщин уже полтора-два,

\footnotetext{
${ }^{1}$ Скорость взросления получена путем деления количества стартовых событий в жизни конкретного индивида на длительность его взросления. Затем на основе индивидуальных «скоростей» взросления была рассчитана средняя «скорость» для каждого поколения. Такой способ расчета дает более точные результаты, нежели простое деление колонки «Количество событий из 5» на «Длительность взросления».
} 
тогда как у мужчин всего 1,3. К 35 годам социоэкономических событий у обоих полов по 2,5, а демографических - у женщин больше двух, а у мужчин - меньше двух.

В среднем, завершение взросления у советских мужчин происходило к возрасту 2628 лет, а у советских женщин - примерно на год раньше. То есть длительность взросления составляла примерно 9-10 лет. Самому молодому поколению россиян на момент опроса было от 25 лет до 31 года, и к этому времени ими накоплено всего 3,6 событий из пяти, поэтому рассчитать средний или медианный возраст завершения взросления для них пока нельзя.

Так как на момент опроса респонденты находились в разных возрастах, у них были разные шансы на наступление стартовых событий. Чтобы нивелировать этот эффект, мы рассчитали относительный показатель «скорости» взросления: для каждого респондента мы разделили длительность взросления на число реализовавшихся событий, а затем посчитали среднее число событий для каждого поколения. «Скорость» взросления показывает, что самое старшее поколение взрослело «медленнее» всех (0,69 события в год). Самое молодое поколение, которое начало переход во взрослую жизнь всего несколько лет назад, показывает почти в 2 раза более высокую скорость взросления (1,23 события в год). Безусловно, это вызвано эффектом возраста: чем старше будет становиться поколение, тем ниже будет скорость взросления.

Выстроив стартовые события в хронологическом порядке внутри каждой биографии, мы определили усредненную последовательность их наступления. Расчеты подтверждают уже имеющиеся эмпирические свидетельства того, что распространенность и последовательность наступления стартовых событий у россиян меняется (Mills 2004; Захаров 2009; Potârcă et al. 2013).

В советское время универсальными событиями были трудоустройство, отделение от родителей и создание семьи, причем наступали они в основном именно в этой последовательности. Получение профессионального образования было в большей степени прерогативой мужчин. В нормативный сценарий взросления у женщин это событие включается только начиная с поколения 1950-59 годов рождения (г.р.). Вступление в партнерство (незарегистрированный союз) в советском обществе не поощрялось, поэтому оно встречается редко. А если это событие и имело место, то в основном после первого брака и последовавшего за ним развода. То есть в советское время партнерство не выполняло роль маркера взрослости, а скорее являлось допустимым событием этапа зрелости.

Наступление стартовых событий в разрезе других индивидуальных характеристик различалось не сильно. У подавляющего большинства респондентов первым событием являлось трудоустройство, а последним - деторождение. У высокообразованных респондентов и жителей областных центров первым событием часто становилось отделение от родителей, скорее всего связанное с образовательной или трудовой мобильностью. А последним событием (наряду с деторождением) оказывалось получение профессионального образования. У женщин появление ребенка снижало шансы трудоустройства и получения профессионального образования. 
В постсоветское время партнерство и получение профессионального образования стали частью нормативного сценария взросления. Добавление этих двух событий в перечень обязательных и/или желательных увеличило разнообразие комбинаций стартовых событий. Нынешняя молодежь, имеющая высокий уровень образования и живущая в областных центрах, начинает взросление с социоэкономических событий, т. е. с инвестиций в свой человеческий капитал и обретения финансовой независимости. Только после этого молодые поколения заводят семью. При этом семейная жизнь у них чаще всего начинается с партнерства, которое не всегда перерастает в брак даже при наличии ребенка. Очередность наступления событий у тех, кто проживает в менее урбанизированных населенных пунктах и имеет более низкий уровень образования, различается в зависимости от гендерной принадлежности: начало перехода во взрослую жизнь у мужчин теперь больше связано с получением образования (часто в комбинации с трудоустройством), а у женщин - со вступлением в партнерство или брак.

\section{КАЛЕНДАРНЫЕ ГОДЫ: ЛОКАЛИЗАЦИЯ ПЕРИОДА ВЗРОСЛЕНИЯ ПОКОЛЕНИЯ НА КОНКРЕТНОМ ИСТОРИЧЕСКОМ ОТРЕЗКЕ}

Поколение 1930-39 г.p. наиболее активный период накопления стартовых событий переживало в период с 1947 по 1966 г. Свое взросление эти респонденты начали в переломную эпоху, когда очередная волна послевоенных репрессий и усиления рестриктивных мер сменилась «оттепелью», либерализацией социально-экономической, образовательной, трудовой, миграционной и семейной политики. В то же время либерализация была непоследовательной и далеко не полной: сохранялись явные черты всеобщей трудовой мобилизации, действовала политика «орабочивания», обязательное распределение на работу после завершения учебы, запрет увольнения и смены работы. Нельзя также забывать и о платности обучения в старших классах школы, средних специальных и высших учебных заведениях (действовало в 1940-1956 гг.), и о более длительных сроках службы в армии по призыву. Рассматриваемое поколение начинало взросление именно с трудоустройства и отодвигало реализацию остальных событий на более поздние возрасты.

В этот период еще отсутствовали нормативы длительности обучения в школе, так что в этом поколении встречаются те, кто окончил всего несколько классов школы и не получал образование более высокого уровня или получал, но поздно - в качестве одного из последних событий в цепочке событий, маркирующих взросление.

Послевоенная диспропорция полов, ведущая к несбалансированности брачного рынка, способствовала серьезному расхождению медианных возрастов наступления демографических событий у мужчин и женщин. Демографические события у данного поколения наступали позже, чем у последующих поколений. Помимо прочего, это было вызвано высокой конкуренцией семейной и трудовой сфер жизни в бюджетах времен, а также только формирующимися и еще не отлаженными институтами государственного вспомоществования (ясли, детские сады, короткий отпуск по беременностям и родам и др.). 
Поколения 1940-49 и 1950-59 г.p. взрослели в более стабильный период советской истории (1957-1985 гг.). Зарегулированность общественной жизни оставалась высокой; рестриктивных мер было довольно много, но государственная поддержка в семейной, образовательной и других сферах жизнедеятельности росла и давала уверенность, что государственные институты помогут реализовать необходимые события и успешно освоить новые социальные роли. Действовавшие «советские» нормы и правила уже были освоены предыдущими поколениями, что облегчало трансляцию нормативных сценариев поведения.

Респонденты, родившиеся в 40-е и 50-е годы, демонстрируют раннее и интенсивное достижение статусов взрослого человека, которое можно описать следующим образом. Наступление стартовых событий у мужчин происходило к 27 годам, у женщин - к 25-26 годам. Усредненная последовательность их наступления выглядела так: сначала трудоустройство и отделение от родителей, затем - создание семьи и завершение профессионального образования. Связь между браком и деторождением была очень сильной (протогенетический интервал составлял менее года). Такая однородность наступления стартовых событий отражала однородность взглядов, условий жизни, доходов, существование единых общественных и законодательных норм, регулирующих время и порядок наступления событий.

Поколение 1960-69 г.p. начало переход во взрослую жизнь в стабильное советское время (1977 г.), а заканчивало - в период перестройки и распада Советского Союза (1994 г.). В результате внешне процесс взросления (последовательность и тайминг наступления событий) у этого поколения выглядит весьма схоже с предшественниками, но более детальное рассмотрение, в частности, гендерных различий, позволяет увидеть наметившиеся изменения, во многом обусловленные ситуативными факторами (изменениями в социоэкономической и демографической политике).

У мужчин этого поколения стартовые события наступают позже, чем у предшественников. В определенной мере, это обусловлено тем, что в 60-е годы снижалась численность когорт по году рождения, а значит, количество призывников 18 лет спустя так же становилось меньше, чем в предыдущие годы. Чтобы скомпенсировать сокращение контингента призывников на срочную армейскую службу, в 80-е был приостановлен ряд отсрочек для поступающих в вузы и ограничено число министерств, предоставлявших отсрочки выпускникам профтехучилищ на время работы в народном хозяйстве [Градосельский, 2005]. После прохождения срочной службы и возвращения домой мужчины начинали «наверстывать» упущенное и завершали взросление даже на год раньше предыдущих поколений.

Женщины этого поколения тоже демонстрируют более раннее завершение взросления, которое было обусловлено снижением возраста рождения первого ребенка. В 1982 г. правительство увеличило оплачиваемый отпуск по уходу за ребенком до 1 года, а в 1989 г. - до полутора лет. Эти меры простимулировали рождаемость среди женщин, родившихся в 60-е годы, параллельно снизив их шансы на получение образования более высокого уровня и трудоустройство. 
Поколение 1970-79 г.р. вступало во взрослую жизнь в очень турбулентное время (1988-2004 гг.) с размытыми ориентирами относительно желаемых, нежелательных и обязательных образцов поведения. Наряду с колоссальным расширением свободы выбора поведенческих практик, возможностей пробовать новое и экспериментировать, вырос и уровень неопределенности, напряженности и рисков: весь период взросления это поколение сталкивалось с экономическими кризисами, с военными действиями в Чечне и межэтническими конфликтами, с нестабильностью социальных институтов - с неизбежностью коррекции своих планов на будущее.

Отмена рестриктивных норм в социоэкономической и демографической сфере позволила этому поколению более свободно организовывать свою жизнь, но в условиях довольно высокой турбулентности и неопределенности: ряд профессий и специальностей перестали быть востребованными, а ключевые предприятия и организации закрывались и/или меняли форму собственности, что вызывало дезориентацию и нередко безработицу, особенно среди молодого поколения, еще не имеющего опыта трудовой занятости и социальных связей. В результате мы видим откладывание возраста первого трудоустройства в этом поколении.

Повышение доступности высшего образования, в том числе, за счет его коммерциализации, вызвало резкий рост предложения и спроса на образовательные услуги. В результате все большее число молодых людей смогло себе позволить «психосоциальный мораторий» (Erikson 1995) в виде студенчества, которое для них было не столько инвестицией в человеческий капитал, сколько способом «пережидания» очередного экономического кризиса и периода неопределенности.

Возраст покидания родительского дома теми, кто родился в 70 -е, совпадает с таймингом предыдущих поколений, так как в государстве еще продолжала действовать инерция выполнения ряда социальных обязательств, в частности обеспечения жильем тех, кто встал в «очередь на улучшение жилищных условий» в советское время. Отмирающие в этот период практики получения жилья (например, общежития, квартиры «гостиничного типа» от работодателей) замещались новыми в связи с развитием и повышением гибкости жилищного рынка, а также в связи с ослаблением соционормативных и законодательных ограничений на проживание с «посторонними» (с партнерами).

Возраст вступления в первое партнерство у этого поколения заметно снизился, а количество таких союзов в жизненном пути, по сравнению с предыдущими поколениями, возросло. Постепенная дестигматизация добрачных сексуальных отношений позволила этому поколению осваивать новые способы совместной жизни. Однако отсутствие знаний о планировании семьи и средствах контрацепции зачастую приводило к добрачным зачатиям. Предыдущие поколения в такой ситуации либо вступали в брак «вдогонку», либо абортировали беременность. Поколения 70-х годов рождения все меньше прибегают к абортам и сохраняют беременность, но практика вступления в брак после зачатия продолжает воспроизводиться. Поэтому протогенетический интервал остается на уровне предыдущих поколений (менее года).

Поколение 1980-86 г.p. - единственное из всех рассматриваемых поколений, взросление которого началось уже по прошествии определенного времени после распада 
СССР (они достигли 15-летнего возраста в 1995 г. или позднее) и для которого расширившаяся свобода выбора и новая информационная среда были естественными компонентами жизни. Достаточно экономически стабильные нулевые годы, восстановление институтов государственной поддержки семьи, открытость государственных границ, возможность аренды и покупки жилья - эти и другие факторы создали для молодого поколения условия для более вариативного, но в то же время защищенного вхождения во взрослую жизнь. Появление Интернета, социальных сетей, возможностей удаленной работы или более свободного ее графика, развитие фармакологического рынка позволили этому поколению успешно освоить новые навыки планирования жизни и семьи, изучить различные варианты формирования жизненного пути, основанные на принципах тайм-менеджмента и осознанного выбора. Отсутствие единого и жестко зафиксированного образца поведения привело к росту разнообразия жизненных стратегий, в частности, демографических, к возможности отказа от каких-то событий, например, от деторождений (Вильданова и др. 2017; Salyakhieva, Saveleva 2017), либо к их отсрочке или же наоборот - к более эффективному совмещению разных сфер жизни, например, родительства и занятости (Billari, Giuntella, Stella 2019).

Стандартные социоэкономические события у поколения 80-х годов рождения наступают примерно в тех же возрастах и с той же интенсивностью, что и у двух предыдущих поколений. Возраст первого трудоустройства немного откладывается, но это объясняется более длительным получением профессионального образования. Среди первых демографических событий предпочтение чаще отдается партнерствам, тогда как события, требующие принятия более долгосрочной ответственности (браки и деторождения), откладываются на более поздние возрасты. Если у мужчин замедление темпов взросления в демографической сфере видно очень отчетливо, то жизненные пути женщин пока еще очень «спрессованы» (уже слабее, чем у женщин предыдущего поколения, но гораздо сильнее, чем у мужчин-ровесников).

Молодежь не уклоняется от взросления, но, становясь активным участником этого процесса, начинает менять его структуру и календарь. Благодаря широкой доступности высшего образования студенческие годы стало возможным вписать в типичный жизненный сценарий молодого россиянина. А это, по Э. Эриксону (Erikson 1995), дает индивидам возможность взять паузу между завершением детства и обретением взрослости («психосоциальный мораторий») и посвятить это время поиску себя и планированию карьеры.

\section{КЛАССИФИКАЦИЯ МОДЕЛЕЙ ВЗРОСЛЕНИЯ}

Предложенный способ визуализации процесса взросления на демографической сетке Лексиса позволяет сделать вывод, что эпоха, в рамках которой поколение реализуют стартовые события взрослой жизни, оказывает влияние на формирование моделей взросления. Переход во взрослую жизнь является изменчивым этапом жизни, адаптирующимся к конкретным условиям среды и помогающим молодому поколению наиболее эффективно и быстро встроиться в действующую социальную систему. 
В качестве наиболее устойчивой и типичной модели можно назвать организацию процесса взросления у поколений 1940-49, 1950-59, 1960-69 г.p. Назовем эту модель «советской». Типичное устройство перехода во взрослую жизнь появилось только вследствие унификации работы социальных институтов в позднесоветское время. В эпоху плановой экономики и плановой организации жизни нормативный жизненный сценарий был очень ясно и четко определен. Следовать ему было просто, так как все институты работали согласованно и ориентировали именно на эту типовую модель.

В периоды перемен и нестабильности индивиды откладывают наступление одних событий и приоритизируют наступление других. Например, поколение 1930-39 г.p., столкнувшееся с послевоенной разрухой и связанными с ней экономическими трудностями своим приоритетом вынужденно сделало трудовую деятельность, остальные события отложив на более поздние возрасты. Поколение 1970-79 г.p. - напротив: в период быстрых социальных и политических трансформаций и невозможности строить надежные планы на будущее реализовало ключевые стартовые события «в ускоренном режиме», то ли «делая запасы впрок», то ли стремясь попробовать все и сразу в условиях небывалой свободы. Такие модели взросления можно назвать «переходными» (или адаптивными, стрессовыми). Они лучше всего демонстрируют адаптивную природу процесса взросления.

Модель взросления, которая формируется у сегодняшней молодежи (поколение 1980-86 г.p.), назовем «постсоветской». Мы видим замедление процесса взросления за счет откладывания наступления демографических событий, которое стало возможным благодаря доступу к информации и технологиям (планирование семьи и контрацепция; расширение набора нормативных моделей, транслирующихся через медиа). Также важным изменением стало добавление нового события в число нормативных (партнерство) и приоритизация события, которое ранее было не столь приоритетным и доступным (получение высшего профессионального образования). Это приводит к изменению не только тайминга и последовательности наступления событий, но и к росту количества стартовых событий и разнообразия наборов возможных жизненных сценариев. Вектор изменений, выбранный российской молодежью, соответствует траектории трансформации моделей взросления в западных странах, описанной авторитетными зарубежными авторами (Billari, Liefbroer 2010): взросление перестает быть «ранним, ускоренным и простым» и становится «поздним, растянутылм и сложным»».

\section{ОБСУЖДЕНИЕ РЕЗУЛЬТАТОВ}

Проведенный комплексный анализ и представленная нами классификация подтверждают идеи Биллари и Лифброера (Billari, Liefbroer 2010) о конвергенции паттернов взросления в развитых странах. Современные российские поколения, начавшие переход во взрослую жизнь после распада СССР, демонстрируют отдаление от типично «советской» модели взросления, которую можно назвать «ранней, ускоренной и простой» («традиционная» модель) и приближение к модели, которая становится все более распространенной в западных странах: «поздней, растянутой $u$ сложной» («современная» модель). Взросление начинается позднее, так как молодежь откладывает наступление всех событий и особенно демографических. Взросление становится более растянутым, так как 
социоэкономические события реализуются всего на год-два позже, нежели в предыдущих поколениях, а демографические события откладываются на несколько лет, что вызывает рост общей длительности перехода и замедление его скорости. Взросление становится более сложным за счет роста вариативности времени и последовательности наступления событий и включения в нормативный жизненный сценарий двух непопулярных ранее событий: получения профессионального образования и партнерства.

Переход от «традиционной» «советской» модели взросления россиян к «современной» «постсоветской» подтверждает историческую стадиальность изменения процесса взросления и демографического поведения как его части (Frejka, Zakharov 2012; Puur et al. 2012a; Puur et al. 2012b). Мы выявили, что изменения в тайминге и интенсивности наступления стартовых событий начались в поколении 1960-69 г.р., но эти трансформации были связаны с эффектом периода: войной в Афганистане и активизацией семейной политики и стимулирования рождаемости в 1980-х годах. Первые устойчивые, поколенческие изменения начинаются с поколений 1970-1979 г.р., начавших менять не только тайминг и интенсивность наступления событий, но и их последовательность и приоритетность относительно друг друга. Поколение 1980-1986 г.р. демонстрирует принципиально другой подход к организации процесса взросления, выдвижение на первый план тех событий, которые дают больше выгод, чем обязательств, и откладывание событий, требующих долгосрочной ответственности.

Исследование также подтверждает сделанные перечисленными авторами оценки разницы между началом демографической модернизации в Европе и в России: если в западноевропейских странах изменения в матримониальном поведении начались с поколения 1960-69 г.р., то в России - спустя 20-25 лет, в поколении 1980-86 г.р. Связка трех видов поведения - сексуального, брачного и репродуктивного - постепенно распадается: дебюты каждого из них не только оказываются разделенными все более длительными интервалами, но и происходят во все более произвольной последовательности. Первое партнерство у молодых россиян все чаще становится первым демографическим событием, деторождение - вторым, а брак либо наступает вскоре после зачатия ребенка, либо может вообще не наступить, что приводит к росту внебрачной рождаемости и снижению брачной.

Рост разнообразия жизненных стратегий, изменение последовательности наступления событий и интервалов между ними, появление возможности организовывать свой жизненный путь в соответствии с собственными интересами - все это наблюдается в молодом поколении россиян и согласуется с предположениями концепщии жизненного nymu (Giddens 1994; Heinz, Marshall 2003; Huinink 2013).

\section{Выводы}

Проведенное исследование показало, что исторический и институциональный контекст, сопутствующий взрослению молодых людей, задает границы и ориентиры для возможных моделей взросления (Berger, Luckmann 1966; Kiernan 2002; Sobotka, Toulemon 2008). Чем больше поддержка государства, тем раньше и интенсивнее происходит взросление, что 
согласуется с имеющимися исследованиями (Cavalli, Galland 1993; Vogel 2002; EspingAndersen 2007; Ejrnœs, Воје 2008). Чем уже коридоры, формируемые общественными и законодательными нормами, тем меньше различий в структуре, тайминге, интенсивности и последовательности наступления стартовых событий (пример поколений 1940-49, 1950-59, 1960-69 г.р.). По мере расширения свободы выбора в организации жизненного пути, молодые люди начинают демонстрировать вариативность всех видов поведения (пример поколений 1980-86 г.p.).

Мы выявили три модели взросления россиян: «советская» (характерна для поколений 1940-49, 1950-59, 1960-69 г.р.), «переходная» (поколения 1930-39 и 1970-79 г.p.) и «постсоветская» (поколения 1980-86 г.р.). Предложенные модели вписываются в классификацию Биллари и Лифрбоера (Billari, Liefbroer 2010): «советская» модель соответствует «традиционной» (тайминг - события наступают в молодых возрастах; интенсивность - малые интервалы между событиями; последовательность наступления событий простая и предсказуемая), а «постсоветская» приближается к «современной» (тайминг - откладывание событий на более поздние возрасты; интенсивность - рост интервалов между событиями; последовательность наступления событий сложная и непредсказуемая). Таким образом, наблюдается конвергенция особенностей перехода во взрослую жизнь в России и в странах, находящихся на более продвинутых этапах демографического перехода, что подтверждает стадиальность модернизационного процесса (Frejka, Zakharov 2012; Puur et al. 2012a; Puur et al. 2012b).

«Современная» модель взросления в Европе в усредненном варианте выглядит так: относительно раннее покидание родительского дома, за которым следует небольшое время проживания без партнера, затем вступление в партнерство, зачатие первого ребенка в относительно позднем возрасте и регистрация брака незадолго до рождения ребенка или вовсе отказ от регистрации брака (Billari, Liefbroer 2010). Наш анализ показал, что последовательность наступления стартовых событий у российской молодежи приближается к современной европейской, но демографические события наступают в России в более ранних возрастах и с более короткими интервалами. То есть композиция взросления у нас становится похожей на европейскую модель, а динамика все еще разная.

Вписывание студенческих лет в нормативный жизненный сценарий современного россиянина дало возможность молодежи использовать время обучения и следующий за ним период начала карьеры как паузу во взрослении («психосоциальный мораторий» (Erikson 1995)). В течение этих нескольких лет молодые россияне находятся в состоянии «полувзрослости»: они уже обрели социоэкономические статусы и опыт проживания с партнером, но еще не создали семью. Вступление в брак и деторождение воспринимаются ими как наиболее «неотменяемые» события, требующие определенной психологической зрелости и финансовой устойчивости. Мы полагаем, что такое удлинение периода взросления - следствие откладывания демографических событий на более поздние возрасты, а не полного отказа от них.

Представленное исследование помогает лучше понять, что представляет из себя современная молодежь и на каком возрастном отрезке она локализуется. Учитывая стремление молодежи к обретению финансовой независимости до вступления в 
брак и деторождения, в качестве эффективной меры можно предложить расширение финансовых инструментов и карьерных возможностей, которые позволят молодежи не задерживаться в периоде «полувзрослости». Также достичь баланса между социоэкономической и демографической сферой поможет более гибкая система совмещения родительства и занятости. Обращаясь к имеющимся примерам трансформации моделей взросления в европейских странах, мы можем спрогнозировать дальнейшие изменения взросления в России и, предвосхитив их, подготовить общество и институты к новым вызовам.

\section{БЛАГОДАРНОСТИ}

Автор выражает благодарность за многолетнюю поддержку и научное консультирование всем коллегам, оказавшим помощь в подготовке данного исследования. Прежде всего, научному руководителю С.В. Захарову, а также участникам двух научно-учебных групп НИУ ВШЭ «Изучение рождаемости, формирования, развития и распада семей на данных выборочных обследований» и «Модели и методы анализа демографических последовательностей», в особенности А.О. Макаренцевой, Д.И. Игнатову, Т.Н. Espy, О.В. Синявской, А.В. Артамоновой, А.А. Муратовой, Д.К. Гиздатуллину, С.С. Бирюковой и А.А. Долговой.

Также автор благодарит за рецензирование разных частей данной работы на разных стадиях ее подготовки коллег из российских и зарубежных университетов и научных центров: А. Puur, В.С. Магуна, Е.Ю. Рождественскую, А.Г. Вишневского, М.С. Фабрикант, А.А. Авдеева, A. Blum, F. Billari, M. Mills, L. Sakkeus, L. Rahnu, P. Blanchard, R. Leu, L. Toulemon, E. Lelièvre, M. Bouchet-Valat, L. Moulin.

\section{ЛИТЕРАТУРА}

Артамонова А.В., Митрофанова Е.С. (2018). Матримониальное поведение россиян на фоне других европейцев. Демографическое обозрение, 5(1), 106-137.

Архангельский В.Н. (2013). Репродуктивное и брачное поведение. Сочиологические исследования, 2, 129-136.

Блюм А., Лефевр С., Себий П., Бадурашвили И., Ренье-Луалье А., Станкуниене В., Синявская О. (2010). Семья в четырех государствах: Франция, Грузия, Литва, Россия. В Эволюичя семьи в Европе: Восток-Запад (сс. 11-41). М.: НИСП.

Блюм А., Себий П., Захаров, С.В. (2010). Взросление во Франции и России: Различия в перспективе поколений. В Эволючия семьи в Европе: Восток-Запад (сс. 141-174). М.: НИСП.

Вильданова С.М., Граничная А.А., Мингалиева А.Р., Саляхиева Л.М. (2017). Тенденции распространения ценностей чайлдфри в России и их влияние на кризис института семьи. Мониторинг общественного мнения: Экономические и соџииальные перемены, 3(139), 192-205.

Гимпельсон В.Е., Зудина А.А. (2017). Демографические проблемы рынка труда. Демоскоп Weekly, 729-730. URL: http://www.demoscope.ru/weekly/2017/0729/tema01.php 
Градосельский В.В. (2005). Комплектование Вооруженных Сил СССР в 1970-1980-е годы. Военно-исторический журнал. 9, 18-21.

Вишневский А. Г. (1976). Демографическая революиия. Москва: Статистика.

Вишневский А.Г. (Ред.) (2006). Демографическая модернизациия России, 1900-2000. Москва: Новое издательство.

Долбик-Воробей Т. (2003). Студенческая молодежь о проблемах брака и рождаемости. Социологические исследования, 11, 78-83.

Захаров С.В. (2007). Трансформация брачно-партнерских отношений в России: «золотой век» традиционного брака близится к закату? В Т.М. Малева, О.В. Синявская (Ред.), Родители и дети, мужчины и женщины в семье и обществе. Выпуск 1 (сс. 75-127). М.: НИСП.

Захаров С.В. (2009). Ценностно-нормативные «расписания» человеческой жизни: Представления жителей разных стран о том, когда девушка становится взрослой. В Россия в Европа. По материалам международного проекта «Европейское сочиальное исследование» (сс. 347-379). М.: Academia.

Здравомыслова О.М., Шурыгина И.И. (2001). Выжить или преуспеть: Представления старшеклассников о своих жизненных шансах. В Кто и куда стремится вести Россию? Акторы макро-, мезо- и микроуровней современного трансформационного прочесса (сс. 366-374). URL: http://ecsocman.hse.ru/data/250/679/1219/048.ZDRAVOMYSLOVA.pdf

Константиновский Д.Л. (2008). Неравенство и образование. Опыт сочиологических исследований жизненного старта российской молодежи (1960-е годы-начало 2000-х). М.: Центр социального прогнозирования.

Лапето А., Терещенко О.В., Шавердо Т. (2018). Переход в самостоятельную жизнь: Возрастные модели жизненных путей В О. Терещенко, Т. Кучера (Ред.), Беларусь: Структура семьи, семейные отношения, репродуктивное поведение. Том II. Анализ результатов исследования «Поколения и гендер» (сс. 14-22). Минск: Белсэнс.

Магун В.С., Энговатов М.В. (2006). Динамика притязаний и изменение ресурсных стратегий молодежи: 1985-2005 годы. Отечественные записки, 3, 76-96.

Мид М. (1988). Культура и мир детства. М.: Наука.

Ремшмидт Х. (1994). Подростковый и юномеский возраст: Проблемы становления личности. URL: http://www.childpsy.ru/lib/books/id/8335.php

Чернова Ж.В. (2012). Специфика гендерных отношений молодых взрослых. Социологические исследования, 7, 118-127.

Шабунова А.А., Калачикова О.Н. (2015). Проблемы трансформации демографических институтов: Семья и брак. Социологический альманах, 6, 151-165.

Ярская-Смирнова Е.Р., Романов П.В. (Ред.) (2008). Советская социальная политика: сиеньл и действующие лища, 1940-1985. М.: ООО «Вариант», ЦСПГИ.

Arnett J.J. (2012). New Horizons in Research on Emerging and Young Adulthood. In Early Adulthood in a Family Context (pp. 231-244). NY: Springer.

Artamonova A.V., Mitrofanova E.S. (2014). Is cohabitation an alternative to marriage in Russia? Political behavior: Race, Ethnicity \& Identity Politics eJournal. 8(134). URL: https://hq.ssrn.com/Journals/IssueProof.cfm?abstractid=2513302\&journalid=999052\&issue_ number $=134 \&$ volume $=8 \&$ journal_type $=\mathrm{CMBO} \&$ function $=$ showissue 
Berger P., Luckmann T. (1966). The Social Construction of Reality: A Treatise in the Sociology of Knowledge. Garden City, NY: First Anchor.

Billari F.C., Hagestad G.O., Liefbroer A.C., Spéder Z. (2005). The Timing of Life: The Organization of the Life Course in Europe. In The timing of life: The organisation of the life course in Europe. URL: http://www.europeansocialsurvey.org/docs/round3/questionnaire/ESS3_billari_proposal.pdf

Billari F.C., Liefbroer A.C. (2010). Towards a new pattern of transition to adulthood? Advances in Life Course Research, 15(2), 59-75.

Billari F.C., Giuntella O., Stella L. (2019). Does broadband Internet affect fertility? Population Studies, 73(3), 297-316. DOI: https://doi.org/10.1080/00324728.2019.1584327

Billari F.C., Liefbroer A.C. (2007). Should I Stay or Should I Go? The Impact of Age Norms on Leaving Home. Demography, 44(1), 181-198. URL: https://link.springer.com/article/10.1353\%2Fdem.2007.0000

Buchmann M. (1989). The script of life in modern society: Entry into adulthood in a changing world. Chicago: University of Chicago Press.

Buchmann M.C., Kriesi I. (2011). Transition to Adulthood in Europe. Annual Review of Sociology, 37, 481-503. DOI: https://doi.org/10.1146/annurev-soc-081309-150212

Ejrnœs A., Boje T.P. (2008). Family Policy and Welfare Regimes. In Report 3: Labour Market and social Policies. Aberdeen: University of Aberdeen.

Cavalli A., Galland O. (Eds.) (1993). L'allongement de la jeunesse. Paris: Actes Sud.

Erikson E.H. (1995). Identity: Youth and Crisis. New York: W.W. Norton \& Company.

Esping-Andersen G. (1990). The Three Worlds of Welfare Capitalism. NJ: Polity Press.

Esping-Andersen G. (2007). Family formation and family dilemmas in contemporary Europe. Fundacio'n BBVA.

Frejka T., Zakharov S. (2012). Comprehensive analyses of fertility trends in the Russian Federation during the past half century. Rostock: Max Planck Institute for Demographic Research (MPIDR working paper WP-2012-027).

Giddens A. (1994). Living in a post-traditional society. Reflexive modernization: Politics, tradition and aesthetics in the modern social order, 56, 100.

Hajnal J. (1965). European marriage patterns in perspective. In Glass D.V., Eversley D.E. (Eds.), Population in history: Essays in historical demography (pp. 101-143). URL: https://www.popline.org/node/517620

Heinz W.R., Marshall V.W. (2003). Social dynamics of the life course: Transitions, institutions, and interrelations. New York: Aldine de Gruyter.

Huinink J. (2013). De-Standardisation or Changing Life Course Patterns? Transition to Adulthood from a Demographic Perspective. In The Demography of Europe (pp. 99-118). Springer, Dordrecht. DOI: https://doi.org/10.1007/978-90-481-8978-6_5

Kiernan K. (2002). Cohabitation in Western Europe: Trends, issues and implications. In Booth A., Crouter A. (Eds.), Just Living Together: Implications of cohabitation on families, children and social policy (pp. 3-31). New York: Lawrence Erlbaum Associates.

Lesthaeghe R. (1995). The second demographic transition in Western countries: An interpretation. In Gender and family change in industrialized countries (pp. 17-62). Oxford: Clarendon Press. 
Lesthaeghe R., Neels K. (2002). From the First to the Second Demographic Transition: An Interpretation of the Spatial Continuity of Demographic Innovation in France, Belgium and Switzerland European. Journal of Population, 18(4), 325-360.

Liefbroer A.C. (1999). From Youth to Adulthood: Understanding Changing Patterns of Family Formation from a Life Course Perspective. In Population Issues (pp. 53-85). The Netherlands: Springer.

Mills M. (2004). Stability and change: The structuration of partnership histories in Canada, the Netherlands, and the Russian Federation. European Journal of Population/Revue européenne de Démographie, 20(2), 141-175.

Potârcă G., Mills M., Lesnard L. (2013). Family Formation Trajectories in Romania, the Russian Federation and France: Towards the Second Demographic Transition? European Journal of Population/Revue européenne de Démographie, 29(1), 69-101. DOI: https://doi.org/10.1007/s10680-012-9279-9

Puur A., Rahnu L., Maslauskaite A., Stankuniene V. (2012a). Past and present patterns of family formation in Eastern Europe: Does Hajnal's delineation still matter? Filosofija Sociologija, 23(4), 256-265.

Puur A., Rahnu L., Maslauskaite A., Stankuniene V., Zakharov S. (2012b). Transformation of Partnership Formation in Eastern Europe: The Legacy of the Past Demographic Divide. Journal of Comparative Family Studies, 43(3), 389-417.

Rindfuss R.R. (1991). The Young Adult Years: Diversity, Structural Change, and Fertility. Demography, 28(4), 493-512. URL: https://link.springer.com/article/10.2307\%2F2061419

Salyakhieva L.M., Saveleva Z.V. (2017). Childfree as a Social Phenomenon: Russians' Attitude to Voluntary Childlessness. Tarih Kültür ve Sanat Araştırmaları Dergisi, 6(4), 531-537. DOI: https://doi.org/10.7596/taksad.v6i4.1144

Shoven J.B., Goda G.S. (2011). Adjusting Government Policies for Age Inflation. In Demography and the Economy (pp. 143-168). DOI: https://doi.org/10.7208/chicago/9780226754758.003.0005

Sobotka T., Toulemon L. (2008). Changing family and partnership behaviour: Common trends and persistent diversity across Europe. Demographic Research, 19, 85-138. DOI: https://doi.org/10.4054/DemRes.2008.19.6

van de Kaa D. J. (1987). Europe's Second Demographic Transition. Population Bulletin, 42, 3 57.

Vogel J. (2002). European Welfare regimes and the transition to adulthood: A comparative and longitudinal perspective. Social Indicators Research, 59, 275-299.

Zakharov S. (2008). Russian Federation: From the first to second demographic transition. Demographic Research, 19, 907-972. DOI: https://doi.org/10.4054/DemRes.2008.19.24

Zsolt S., Murinkó L., Settersten Jr.R.A. (2014). Are Conceptions of Adulthood Universal and Unisex? Ages and Social Markers in 25 European Countries. Social Forces, 92(3), 873-898. DOI: https://doi.org/10.1093/sf/sot100 


\title{
MODELS OF THE TRANSITION TO ADULTHOOD OF DIFFERENT RUSSIAN GENERATIONS
}

\author{
EKATERINA MITROFANOVA
}

\begin{abstract}
This paper is devoted to the analysis of the starting events marking the transition to adulthood, such as completion of education (vocational and higher), first employment, first leaving parents first time leaving home, first partnership, first marriage, and first childbirth.

The dataset of the research is the Russian part of the Generations and Gender Programme (GGS). We prepared the harmonised dataset of the three waves (2004, 2007, and 2011), which included 5,451 respondents born between 1930 and 1986. We used two complementary approaches to study the transition to adulthood: the analysis of the starting sociodemographic events separately and the analysis of all of them as a part of one process. We plotted the results of the analysis on a demographic Lexis grid, which allowed us to observe the influence of the historical and institutional context on people's behaviour.
\end{abstract}

The research revealed three models of the transition to adulthood in Russia: "Soviet" (generations of 194049, 1950-59, and 1960-69), "Transitional" (generations of 1930-39 and 1970-79), and "Post-Soviet" (generation of 1980-86). Our classification is similar to the idea of the convergence of the patterns of the starting events' occurrence (Billari and Liefbroer 2007), which assumes a change from the "traditional" model ("early, contracted and simple") to the "modern" model ("late, protracted and complex"). The similarity of the changes in Russian and European models confirms the stadiality of the modernisation process (Frejka and Zakharov 2012; Puur et al. 2012). The study also confirms the assumption of the life course approach about the individualisation of the life course.

Key words Russia, transition to adulthood, generations, starting life course events, demographic events, socioeconomic events, demographic transition, marriage, childbearing, partnership, employment, education, leaving parents.

EKATERINA MITROFANOva (mitrofanovy@yandex.ru), NATIONAL RESEARCH UNIVERSITY Higher SCHOOL OF Economics, The Russian Presidential ACAdemy of National Economy and Public Administration, Russia.

THIS ARTICLE IS THE PRODUCT OF A RESEARCH PROJECT IMPLEMENTED AS PART OF THE BASIC RESEARCH PROGRAMME AT THE NATIONAL ReSEARCH University Higher SCHOOL OF ECONOMICS (HSE) 2019.

DATE RECEIVED : NOVEMBER 2019.

\section{REFERENCES}

Arkhangel'skij V.N. (2013). Reproduktivnoe i brachnoe povedenie [Reproductive and marital behavior]. Sociologicheskie issledovaniya [Sociological studies], 2, 129-136. (In Russ.).

Arnett J.J. (2012). New Horizons in Research on Emerging and Young Adulthood. In Early Adulthood in a Family Context (pp. 231-244). NY: Springer.

Artamonova A.V., Mitrofanova E.S. (2014). Is cohabitation an alternative to marriage in Russia? Political behavior: Race, Ethnicity \& Identity Politics eJournal. 8(134). URL: https://hq.ssrn.com/Journals/IssueProof.cfm?abstractid=2513302\&journalid=999052\&issue_ number $=134 \&$ volume $=8 \&$ journal_type $=\mathrm{CMBO} \&$ function $=$ showissue

Artamonova A.V., Mitrofanova E.S. (2018). Matrimonial'noe povedenie rossiyan na fone drugih evropejcev [Matrimonial behavior of Russians in the European context]. Demograficheskoe obozrenie [Demographic Review], 5(1), 106-137. (In Russ.). 
Berger P., Luckmann T. (1966). The Social Construction of Reality: A Treatise in the Sociology of Knowledge. Garden City, NY: First Anchor.

Billari F.C., Giuntella O., Stella L. (2019). Does broadband Internet affect fertility? Population Studies, 73(3), 297-316. DOI: https://doi.org/10.1080/00324728.2019.1584327

Billari F.C., Hagestad G.O., Liefbroer A.C., Spéder Z. (2005). The Timing of Life: The Organization of the Life Course in Europe. In The timing of life: The organisation of the life course in Europe. URL:

http://www.europeansocialsurvey.org/docs/round3/questionnaire/ESS3_billari_proposal.pdf

Billari F.C., Liefbroer A.C. (2007). Should I Stay or Should I Go? The Impact of Age Norms on Leaving Home. Demography, 44(1), 181-198. URL:

https://link.springer.com/article/10.1353\%2Fdem.2007.0000

Billari F.C., Liefbroer A.C. (2010). Towards a new pattern of transition to adulthood? Advances in Life Course Research, 15(2), 59-75.

Blum A., Lefèvre C., Sebille P., Badurashvili I., Régnier-Loilier A., Stankuniene V., Sinyavskaya O. (2010). Sem'ya v chetyrekh gosudarstvah: Franciya, Gruziya, Litva, Rossiya [Family in four states: France, Georgia, Lithuania, Russia]. In Evolyuciya sem'i v Evrope: Vostok-Zapad [Evolution of the Family in Europe: East-West] (pp. 11-41). Moscow: NISP. (In Russ.).

Blum A., Sebij P., Zakharov S.V. (2010). Vzroslenie vo Francii i Rossii: Razlichiya v perspektive pokolenij [Growing up in France and Russia: Differences in generational perspective]. In Evolyuciya sem'i v Evrope: Vostok-Zapad [Evolution of the Family in Europe: East-West] (pp. 141-174). Moscow: NISP. (In Russ.).

Buchmann M. (1989). The script of life in modern society: Entry into adulthood in a changing world. Chicago: University of Chicago Press.

Buchmann M.C., Kriesi I. (2011). Transition to Adulthood in Europe. Annual Review of Sociology, 37, 481-503. DOI: https://doi.org/10.1146/annurev-soc-081309-150212

Cavalli A., Galland O. (Eds.) (1993). L'allongement de la jeunesse. Paris: Actes Sud.

Chernova Zh.V. (2012). Specifika gendernyh otnoshenij molodyh vzroslyh [Specificity of gender relations of young adults]. Sociologicheskie issledovaniya [Sociological Studies], 7, 118-127. (In Russ.)

Dolbik-Vorobej T. (2003). Studencheskaya molodezh' o problemah braka i rozhdaemosti [Student youth about the problems of marriage and fertility]. Sociologicheskie issledovaniya [Sociological Studies], 11, 78-83. (In Russ.).

Ejrnœs A., Boje T.P. (2008). Family Policy and Welfare Regimes. In Report 3: Labour Market and social Policies. Aberdeen: University of Aberdeen.

Erikson E.H. (1995). Identity: Youth and Crisis. New York: W.W. Norton \& Company.

Esping-Andersen G. (1990). The Three Worlds of Welfare Capitalism. NJ: Polity Press.

Esping-Andersen G. (2007). Family formation and family dilemmas in contemporary Europe. Fundacio'n BBVA.

Frejka T., Zakharov S. (2012). Comprehensive analyses of fertility trends in the Russian Federation during the past half century. Rostock: Max Planck Institute for Demographic Research (MPIDR working paper WP-2012-027). 
Giddens A. (1994). Living in a post-traditional society. Reflexive modernization: Politics, tradition and aesthetics in the modern social order, 56, 100.

Gimpel'son V.E., Zudina A.A. (2017). Demograficheskie problemy rynka truda [Demographic problems of the labour market]. Demoscope Weekly, 729-730. (In Russ.). URL: http://www.demoscope.ru/weekly/2017/0729/tema01.php

Gradoselskiy V. (2005). Komplektovanie vooruzhennih sil SSSR v 1970-1980-e gody [Completion of Soviet Union armed forces in 1970-1980]. Voenno-istoricheskiy zhurnal [War-historical Journal], 9, 18-21. (In Russ.).

Hajnal J. (1965). European marriage patterns in perspective. In Glass D.V., Eversley D.E. (Eds.), Population in history: Essays in historical demography (pp. 101-143). URL: https://www.popline.org/node/517620

Heinz W.R., Marshall V.W. (2003). Social dynamics of the life course: Transitions, institutions, and interrelations. New York: Aldine de Gruyter.

Huinink J. (2013). De-Standardisation or Changing Life Course Patterns? Transition to Adulthood from a Demographic Perspective. In The Demography of Europe (pp. 99-118). Springer, Dordrecht. DOI: https://doi.org/10.1007/978-90-481-8978-6_5

Inglhart R. (2018). Kul'turnaya evolyuciya. Kak izmenyayutsya chelovecheskie motivacii i kak eto menyaet mir [Cultural evolution. How human motivations change and how it changes the world]. (In Russ.). URL: https://sotsium.ru/uploads/files/demo-mysl/inglehart_p1-40.pdf

Kiernan K. (2002). Cohabitation in Western Europe: Trends, issues and implications. In Booth A., Crouter A. (Eds.), Just Living Together: Implications of cohabitation on families, children and social policy (pp. 3-31). New York: Lawrence Erlbaum Associates.

Konstantinovskij D.L. (2008). Neravenstvo i obrazovanie. Opyt sociologicheskih issledovanij zhiznennogo starta rossijskoj molodezhi (1960-e gody-nachalo 2000-h) [Inequality and education. Experience of sociological research of life start of Russian youth (1960s-early 2000s)]. Moscow: Centr social'nogo prognozirovaniya. (In Russ.)

Lapeto A., Tereshchenko O.V., Shaverdo T. (2018). Perekhod v samostoyatel'nuyu zhizn': Vozrastnye modeli zhiznennyh putej [Transition to independent life: Age models of life paths]. In O. Tereshchenko, T. Kuchera (Eds.), Belarus': Struktura sem'i, semejnye otnosheniya, reproduktivnoe povedenie: Tom II. Analiz rezul'tatov issledovaniya "Pokoleniya $i$ gender» [Belarus: Family structure, family relations, reproductive behavior: Vol. II. Analysis of the results of Generations and Gender Survey] (pp. 14-22). Minsk: Belsens. (In Russ.)

Lesthaeghe R. (1995). The second demographic transition in Western countries: An interpretation. In Gender and family change in industrialized countries (pp. 17-62). Oxford: Clarendon Press.

Lesthaeghe R., Neels K. (2002). From the First to the Second Demographic Transition: An Interpretation of the Spatial Continuity of Demographic Innovation in France, Belgium and Switzerland European. Journal of Population, 18(4), 325-360.

Liefbroer A.C. (1999). From Youth to Adulthood: Understanding Changing Patterns of Family Formation from a Life Course Perspective. In Population Issues (pp. 53-85). The Netherlands: Springer.

Magun V.S., Engovatov M.V. (2006). Dinamika prityazanij i izmenenie resursnyh strategij molodezhi: 1985-2005 gody [Trends in claims and changes in resource strategies of young people: 1985-2005]. Otechestvennye zapiski [Annals of the Fatherland], 3, 76-96. (In Russ.) 
Mead M. (1988). Kul'tura i mir detstva [Culture and the world of childhood]. Moscow: Nauka. (In Russ.)

Mills M. (2004). Stability and change: The structuration of partnership histories in Canada, the Netherlands, and the Russian Federation. European Journal of Population/Revue européenne de Démographie, 20(2), 141-175.

Potârcă G., Mills M., Lesnard L. (2013). Family Formation Trajectories in Romania, the Russian Federation and France: Towards the Second Demographic Transition? European Journal of Population/Revue européenne de Démographie, 29(1), 69-101. DOI: https://doi.org/10.1007/s10680-012-9279-9

Puur A., Rahnu L., Maslauskaite A., Stankuniene V. (2012a). Past and present patterns of family formation in Eastern Europe: Does Hajnal's delineation still matter? Filosofija Sociologija, 23(4), 256-265.

Puur A., Rahnu L., Maslauskaite A., Stankuniene V., Zakharov S. (2012b). Transformation of Partnership Formation in Eastern Europe: The Legacy of the Past Demographic Divide. Journal of Comparative Family Studies, 43(3), 389-417.

Remshmidt H. (1994). Podrostkovyj i yunosheskij vozrast: Problemy stanovleniya lichnosti [Adolescence and youth: Problems of personality formation]. (In Russ.) URL: http://www.childpsy.ru/lib/books/id/8335.php

Rindfuss R.R. (1991). The Young Adult Years: Diversity, Structural Change, and Fertility. Demography, 28(4), 493-512. URL: https://link.springer.com/article/10.2307\%2F2061419

Salyakhieva L.M., Saveleva Z.V. (2017). Childfree as a Social Phenomenon: Russians' Attitude to Voluntary Childlessness. Tarih Kültür ve Sanat Araştırmaları Dergisi, 6(4), 531-537. DOI: https://doi.org/10.7596/taksad.v6i4.1144

Shabunova A.A., Kalachikova O.N. (2015). Problemy transformacii demograficheskih institutov: Sem'ya i brak [Challenges to the transformation of demographic institutions: Family and marriage]. Sociologicheskij al'manah [Sociological almanac], 6, 151-165. (In Russ.)

Shoven J.B., Goda G.S. (2011). Adjusting Government Policies for Age Inflation. In Demography and the Economy (pp. 143-168). DOI: https://doi.org/10.7208/chicago/9780226754758.003.0005

Sobotka T., Toulemon L. (2008). Changing family and partnership behaviour: Common trends and persistent diversity across Europe. Demographic Research, 19, 85-138. DOI: https://doi.org/10.4054/DemRes.2008.19.6

van de Kaa D. J. (1987). Europe's Second Demographic Transition. Population Bulletin, 42, 357.

Vil'danova S.M., Granichnaya A.A., Mingalieva A.R., Salyahieva L.M. (2017). Tendencii rasprostraneniya cennostej chajldfri v Rossii i ih vliyanie na krizis instituta sem'i [Trends in the spread of childfrey values in Russia and their impact on the crisis of the institution of the family]. Monitoring obshchestvennogo mneniya: Ekonomicheskie $i$ social'nye peremeny [Monitoring of Public Opinion: Economic and Social Changes Journal], 3(139), 192-205. (In Russ.).

Vishnevsky A.G. (1976). Demograficheskaja revolutsija. Moscow: Statistics. (In Russ.).

Vishnevsky A.G. (Ed.) (2006). Demograficheskaja modernizacija Rossii, 1900-2000

[Demographic modernization of Russia, 1900-2000]. Moscow: Novoe izdatel'stvo. (In Russ.). 
Vogel J. (2002). European Welfare regimes and the transition to adulthood: A comparative and longitudinal perspective. Social Indicators Research, 59, 275-299.

Yarskaya-Smirnova E.R., Romanov P.V. (Eds.) (2008). Sovetskaya social'naya politika: sceny $i$ dejstvuyushchie lica, 1940-1985 [Soviet social policy: scenes and actors, 1940-1985]. Moscow: OOO Variant, CSPGI. (In Russ.)

Zakharov S. (2008). Russian Federation: From the first to second demographic transition. Demographic Research, 19, 907-972. DOI: https://doi.org/10.4054/DemRes.2008.19.24

Zakharov S.V. (2007). Transformaciya brachno-partnerskih otnoshenij v Rossii: «zolotoj vek» tradicionnogo braka blizitsya $\mathrm{k}$ zakatu? [Transformation of marriage-partnership relations in Russia: the "golden age" of traditional marriage is nearing sunset?]. In T.M. Maleva, O.V. Sinyavskaya (Eds.), Roditeli i deti, muzhchiny $i$ zhenshchiny $v$ sem'e $i$ obshchestve [Parents and children, men and women in the family and society]. Vol. 1 (pp. 75-127). Moscow: NISP. (In Russ.).

Zakharov S.V. (2009). Cennostno-normativnye «raspisaniya» chelovecheskoj zhizni: Predstavleniya zhitelej raznyh stran o tom, kogda devushka stanovitsya vzrosloj [Valuenormative "schedules" of human life: Perceptions of people in different countries about when a girl becomes an adult]. In Rossiya v Evrope. Po materialam mezhdunarodnogo proekta «Evropejskoe social'noe issledovanie». [To Russia in Europe. Based on the international project "European Social Study"] (pp. 347-379). Moscow: Academia. (In Russ.).

Zdravomyslova O. M., Shurygina I.I. (2001). Vyzhit' ili preuspet': Predstavleniya starsheklassnikov o svoih zhiznennyh shansah [Survive or succeed: High school students "perceptions of their life chances]. In Kto i kuda stremitsya vesti Rossiyu? Aktory makro-, mezo- i mikrourovnej sovremennogo transformacionnogo processa [Who and Where Does Russia Seek to Lead? Actors of macro-, meso- and micro-levels of the modern transformation process] (pp. 366-374). (In Russ.). URL: http://ecsocman.hse.ru/data/250/679/1219/048.Zdravomyslova.pdf

Zsolt S., Murinkó L., Settersten Jr.R.A. (2014). Are Conceptions of Adulthood Universal and Unisex? Ages and Social Markers in 25 European Countries. Social Forces, 92(3), 873-898. DOI: https://doi.org/10.1093/sf/sot100 


\section{ПРИЛОЖЕНИЯ}

\section{Приложение 1. Числа респондентов, у которых наступило или не} наступило каждое из стартовых событий, в разрезе пола и поколений

\begin{tabular}{|c|c|c|c|c|c|c|c|c|c|c|c|c|c|}
\hline \multirow[b]{2}{*}{ События } & \multirow[b]{2}{*}{ Поколения } & \multicolumn{6}{|c|}{ Мужчины } & \multicolumn{6}{|c|}{ Женщины } \\
\hline & & $0-14$ & $15-24$ & $25-34$ & $35+$ & $\begin{array}{c}\text { нет } \\
\text { события }\end{array}$ & всего & $0-14$ & $15-24$ & $25-34$ & $35+$ & $\begin{array}{c}\text { нет } \\
\text { события }\end{array}$ & всего \\
\hline \multirow{6}{*}{ 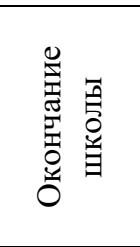 } & 1930-39 & 52 & 141 & 0 & 0 & 0 & 193 & 144 & 444 & 0 & 0 & 1 & 589 \\
\hline & $1940-49$ & 32 & 184 & 0 & 0 & 0 & 216 & 56 & 498 & 0 & 0 & 0 & 554 \\
\hline & $1950-59$ & 16 & 377 & 0 & 0 & 0 & 393 & 37 & 903 & 0 & 0 & 0 & 940 \\
\hline & $1960-69$ & 23 & 410 & 0 & 0 & 0 & 433 & 32 & 740 & 0 & 0 & 0 & 772 \\
\hline & $1970-79$ & 49 & 293 & 0 & 0 & 0 & 342 & 53 & 552 & 0 & 0 & 0 & 605 \\
\hline & $1980-86$ & 19 & 162 & 0 & 0 & 0 & 181 & 13 & 220 & 0 & 0 & 0 & 233 \\
\hline \multirow{6}{*}{ 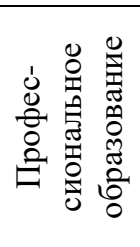 } & 1930-39 & 0 & 79 & 50 & 30 & 34 & 193 & 0 & 203 & 93 & 51 & 242 & 589 \\
\hline & $1940-49$ & 0 & 98 & 47 & 28 & 43 & 216 & 0 & 246 & 102 & 42 & 164 & 554 \\
\hline & $1950-59$ & 0 & 227 & 83 & 15 & 68 & 393 & 0 & 566 & 152 & 65 & 157 & 940 \\
\hline & $1960-69$ & 0 & 276 & 65 & 25 & 67 & 433 & 0 & 523 & 84 & 42 & 123 & 772 \\
\hline & $1970-79$ & 0 & 244 & 54 & 5 & 39 & 342 & 0 & 390 & 125 & 21 & 69 & 605 \\
\hline & $1980-86$ & 0 & 136 & 20 & 0 & 25 & 181 & 0 & 173 & 32 & 0 & 28 & 233 \\
\hline \multirow{6}{*}{ 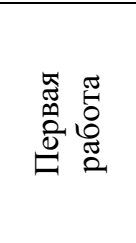 } & 1930-39 & 23 & 160 & 9 & 1 & 0 & 193 & 57 & 488 & 39 & 5 & 0 & 589 \\
\hline & $1940-49$ & 11 & 194 & 9 & 2 & 0 & 216 & 16 & 511 & 24 & 3 & 0 & 554 \\
\hline & $1950-59$ & 4 & 367 & 20 & 1 & 1 & 393 & 5 & 907 & 25 & 1 & 2 & 940 \\
\hline & $1960-69$ & 8 & 405 & 18 & 2 & 0 & 433 & 8 & 723 & 26 & 1 & 14 & 772 \\
\hline & $1970-79$ & 6 & 310 & 23 & 1 & 2 & 342 & 4 & 533 & 50 & 0 & 18 & 605 \\
\hline & $1980-86$ & 1 & 164 & 10 & 0 & 6 & 181 & 0 & 205 & 10 & 0 & 18 & 233 \\
\hline \multirow{6}{*}{ 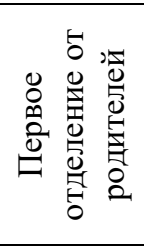 } & 1930-39 & 3 & 130 & 40 & 20 & 0 & 193 & 18 & 458 & 74 & 39 & 0 & 589 \\
\hline & $1940-49$ & 8 & 156 & 36 & 16 & 0 & 216 & 5 & 442 & 71 & 35 & 1 & 554 \\
\hline & $1950-59$ & 3 & 288 & 76 & 22 & 4 & 393 & 10 & 757 & 112 & 47 & 14 & 940 \\
\hline & $1960-69$ & 4 & 324 & 75 & 14 & 16 & 433 & 10 & 642 & 89 & 17 & 14 & 772 \\
\hline & 1970-79 & 2 & 266 & 53 & 3 & 18 & 342 & 13 & 490 & 66 & 4 & 32 & 605 \\
\hline & $1980-86$ & 5 & 112 & 19 & 0 & 45 & 181 & 5 & 181 & 10 & 0 & 37 & 233 \\
\hline \multirow{6}{*}{ 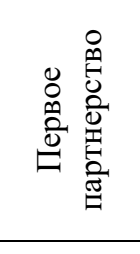 } & 1930-39 & 0 & 29 & 12 & 22 & 130 & 193 & 0 & 95 & 43 & 61 & 390 & 589 \\
\hline & $1940-49$ & 0 & 29 & 17 & 23 & 147 & 216 & 0 & 107 & 46 & 54 & 347 & 554 \\
\hline & $1950-59$ & 2 & 62 & 41 & 42 & 246 & 393 & 3 & 187 & 121 & 112 & 517 & 940 \\
\hline & $1960-69$ & 0 & 99 & 69 & 30 & 235 & 433 & 0 & 212 & 90 & 68 & 402 & 772 \\
\hline & $1970-79$ & 1 & 126 & 72 & 3 & 140 & 342 & 2 & 263 & 92 & 6 & 242 & 605 \\
\hline & $1980-86$ & 0 & 111 & 14 & 0 & 56 & 181 & 0 & 149 & 16 & 0 & 68 & 233 \\
\hline \multirow{6}{*}{ 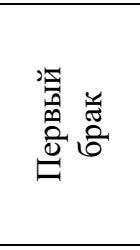 } & & 0 & 93 & 82 & 9 & 9 & 19 & 0 & 387 & 105 & 17 & 80 & 589 \\
\hline & $1940-49$ & 0 & 137 & 64 & 6 & 9 & 216 & 0 & 391 & 85 & 12 & 66 & 554 \\
\hline & $1950-59$ & 0 & 261 & 91 & 16 & 25 & 393 & 1 & 686 & 140 & 20 & 93 & 940 \\
\hline & $1960-69$ & 0 & 261 & 115 & 12 & 45 & 433 & 0 & 593 & 86 & 8 & 85 & 772 \\
\hline & $1970-79$ & 0 & 191 & 68 & 3 & 80 & 342 & 0 & 460 & 45 & 4 & 96 & 605 \\
\hline & $0-86$ & 0 & 41 & 14 & 0 & 126 & 181 & 0 & 106 & 12 & 0 & 115 & 233 \\
\hline \multirow{6}{*}{ 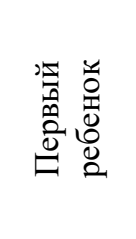 } & 1930-39 & 0 & 62 & 105 & 11 & 15 & 193 & 0 & 370 & 164 & 11 & 44 & 589 \\
\hline & $1940-49$ & 0 & 110 & 96 & 2 & 8 & 216 & 0 & 366 & 134 & 12 & 42 & 554 \\
\hline & $1950-59$ & 0 & 202 & 141 & 14 & 36 & 393 & 0 & 633 & 229 & 26 & 52 & 940 \\
\hline & $1960-69$ & 0 & 218 & 160 & 16 & 39 & 433 & 0 & 573 & 146 & 7 & 46 & 772 \\
\hline & $1970-79$ & 0 & 152 & 120 & 4 & 66 & 342 & 0 & 463 & 94 & 3 & 45 & 605 \\
\hline & $1980-86$ & 0 & 36 & 38 & 0 & 107 & 181 & 0 & 140 & 22 & 0 & 71 & 233 \\
\hline
\end{tabular}

Источник: Составлено автором на основе панельных данных РиДМиЖ на 20112 


\section{Приложение 2. Медианные возрасты наступления стартовых событий}

\begin{tabular}{|c|c|c|c|c|c|c|c|}
\hline Поколение & $\begin{array}{c}\text { Окончание } \\
\text { школы }\end{array}$ & $\begin{array}{c}\text { Профессиональное } \\
\text { образование }\end{array}$ & $\begin{array}{l}\text { Первая } \\
\text { работа }\end{array}$ & $\begin{array}{c}\text { Первое } \\
\text { отделение от } \\
\text { родителей }\end{array}$ & $\begin{array}{c}\text { Первое } \\
\text { партнерство }\end{array}$ & $\begin{array}{c}\text { Первый } \\
\text { брак }\end{array}$ & $\begin{array}{l}\text { Первый } \\
\text { ребенок }\end{array}$ \\
\hline \multicolumn{8}{|c|}{ Мужчины } \\
\hline 1930-1939 & 16 & 25 & 17 & 22 & 26 & 24 & 26 \\
\hline 1940-1949 & 17 & 24 & 18 & 21 & 27 & 23 & 24 \\
\hline 1950-1959 & 17 & 21 & 18 & 21 & 25 & 23 & 24 \\
\hline $1960-1969$ & 17 & 21 & 20 & 20 & 25 & 23 & 24 \\
\hline 1970-1979 & 16 & 20 & 20 & 20 & 23 & 23 & 24 \\
\hline 1980-1986 & 17 & 21 & 20 & 19 & 20 & 22 & 25 \\
\hline Всего & 17 & 21 & 19 & 20 & 23 & 23 & 24 \\
\hline \multicolumn{8}{|c|}{ Женщины } \\
\hline 1930-1939 & 16 & 23 & 18 & 20 & 25 & 22 & 23 \\
\hline 1940-1949 & 17 & 23 & 18 & 20 & 24 & 21 & 22 \\
\hline $1950-1959$ & 17 & 21 & 18 & 19 & 26 & 21 & 22 \\
\hline 1960-1969 & 17 & 20 & 18 & 19 & 23 & 20 & 21 \\
\hline $1970-1979$ & 17 & 21 & 19 & 19 & 20 & 20 & 21 \\
\hline 1980-1986 & 17 & 21 & 20 & 19 & 19 & 20 & 21 \\
\hline Всего & 17 & 21 & 18 & 19 & 23 & 21 & 22 \\
\hline \multicolumn{8}{|c|}{ Bce } \\
\hline 1930-1939 & 16 & 24 & 18 & 20 & 25 & 23 & 24 \\
\hline 1940-1949 & 17 & 23 & 18 & 20 & 25 & 22 & 23 \\
\hline 1950-1959 & 17 & 21 & 18 & 20 & 26 & 22 & 23 \\
\hline $1960-1969$ & 17 & 20 & 19 & 19 & 23 & 21 & 22 \\
\hline $1970-1979$ & 16 & 21 & 19 & 19 & 22 & 21 & 22 \\
\hline $1980-1986$ & 17 & 21 & 20 & 19 & 20 & 21 & 22 \\
\hline Всего & 17 & 21 & 19 & 20 & 23 & 21 & 23 \\
\hline
\end{tabular}

Источник: Составлено автором на основе панельных данных РиДМиЖ на 2011 г.

\section{Приложение 3. Медианные возрасты наступления первого и последнего} события перехода во взрослую жизнь, а также медианная длительность взросления

\begin{tabular}{l|c|c|c|c}
\hline Пол & Поколения & $\begin{array}{c}\text { Медианный возраст } \\
\text { наступления первого } \\
\text { события }\end{array}$ & $\begin{array}{c}\text { Медианный возраст } \\
\text { наступления последнего } \\
\text { события }\end{array}$ & $\begin{array}{c}\text { Медианная } \\
\text { длительность } \\
\text { взросления }\end{array}$ \\
\hline \multirow{5}{*}{ Мужчины } & $1930-39$ & 17 & 30 & 12,8 \\
& $1940-49$ & 17 & 27 & 9,7 \\
& $1950-59$ & 17 & 27 & 9,3 \\
& $1960-69$ & 18 & 26 & 8,3 \\
Женщины, & 26 & 5,7 \\
& $1970-79$ & 18 & 24 & 8,3 \\
& $1980-86$ & 18 & 26 & 7,8 \\
& $1930-39$ & 18 & 26 & 7,9 \\
& $1940-49$ & 17 & 25 & 6,1 \\
\hline
\end{tabular}

Источник: Составлено автором на основе панельных данных РиДМиЖ на 2011 г. 


\section{Приложение 4. Количество стартовых событий и «скорость» взросления} в разрезе поколений

\begin{tabular}{l|c|c|c|c|c|c}
\hline Поколения & \multicolumn{2}{|c|}{$\begin{array}{c}\text { Количество стартовых событий в разрезе } \\
\text { поколений }\end{array}$} & \multicolumn{2}{|c}{ «Скорость» взросления в разрезе поколений } \\
\cline { 2 - 7 } & среднее & $\begin{array}{c}\text { количество } \\
\text { респондентов }\end{array}$ & $\begin{array}{c}\text { стандартное } \\
\text { отклонение }\end{array}$ & среднее & $\begin{array}{c}\text { количество } \\
\text { респондентов }\end{array}$ & $\begin{array}{c}\text { стандартное } \\
\text { отклонение }\end{array}$ \\
\hline $1930-39$ & 4,46 & 782 & 0,685 & 0,69 & 695 & 0,792 \\
$1940-49$ & 4,57 & 770 & 0,632 & 0,80 & 673 & 1,223 \\
$1950-59$ & 4,66 & 1333 & 0,601 & 0,81 & 1105 & 1,069 \\
$1960-69$ & 4,63 & 1205 & 0,675 & 0,95 & 999 & 1,064 \\
$1970-79$ & 4,51 & 947 & 0,818 & 1,06 & 770 & 1,277 \\
$1980-86$ & 3,60 & 414 & 1,161 & 1,23 & 276 & 2,391 \\
Всего & 4,50 & 5451 & 0,776 & 0,89 & 4518 & 1,223 \\
\hline
\end{tabular}

Источник: Составлено автором на основе панельных данных РиДМиЖ на 2011 г. 